\title{
Problematizing Local Knowledge Preservation of the Complex Social Assemblage in Globalizing Tai Lue communities in Chiang Kham
}

\author{
Navaporn Sunanlikanon \\ Faculty of Social Sciences, Chiang Mai University, Chiang Mai 50200, Thailand \\ *Corresponding author. E-mail: nsun808@aucklanduni.ac.nz \\ https://doi.org/10.12982/CMUJASR.2020.0010
}

\begin{abstract}
This article proposes to look at local knowledge preservation as a continual and contested process rather than as a static social activity. The preservation of local knowledge should be studied by situating it within a complex set of relationships among various social actors and organizations, and also within specific spatio-temporal conditions: in this case, the Tai Lue people of Chiang Kham, Phayao, Thailand. The local knowledge of the Tai Lue in Chiang Kham has been revived in accordance with the distinct desires of the local people, local politicians, academic institutions, and local and national governmental sectors. These various agents and organizations make up a social assemblage, in which local knowledge revival and preservation projects take place within a space where distinct cultural, political, and economic meanings are contested. This paper seeks to examine this social activity using the analytical perspective of glocalization. Taking a glocalization approach, local knowledge preservation is problematized as a culturally and socially instrumentalized activity that is pursued by some actors for political and economic identity negotiation. This will be complemented with a strategic essentialism analysis, which can help better illustrate how Tai Lue people utilize their local knowledge to benefit their positions within an increasingly globalized Chiang Kham.
\end{abstract}

Keywords: Glocalization, Local knowledge, Social assemblage, Strategic essentialism, Tai Lue

\section{INTRODUCTION}

The Lue ${ }^{1}$ people have settled in Chiang Kham, Phayao, Thailand for over a hundred years. They have lived in peace with the Lanna people, even though they were immigrants and new settlers (The History of Tai Lue in Chiang Kham, Baan

\footnotetext{
${ }^{1}$ Here, 'Lue' will refer to the Lue heritage that the Lue people trace back to their cultural homeland of Sipsongpanna. This includes their historical originality, their indigenous knowledge of performing rituals, dressing, weaving, art performances, etc. On the other hand, 'Tai Lue' refers to Tai Lue people who have adjusted their lifestyles and developed their livelihood according to the present globalized world. These two notions of 'Lue' and 'Tai Lue' are inspired by and complemented with the work of Nakan Anukunwathaka, entitled "Chiang Kham: Tai Lue town under the movement of localism" (Anukunwathaka, 2013).
} 
That Sop Wean Village, Yuan Subdistrict, Chiang Kham District, Phayao Province, 1977.. Ever since the implementation of a Lue cultural revival project in Chiang Kham, local history has become reconstructed using the oral histories and collective memories of the elders of the community. The understanding that the Lue and Lanna people have lived happily for generations is one of the historical narratives that has been reinvented and transmitted by a local sage who specializes in Tai Lue village history. The sage tells the story of how many Lue people were forced to move from their hometown, Sipsongpanna, to various Lanna principalities due to several civil wars and political unrest caused by the Sipsongpanna nobles. Alongside this, various cultural elements have been rediscovered and reinvented to strengthen Lue identity in present day Chiang Kham. Taken from the Lue cultural revival project, the process of local knowledge recovery and preservation seems to be an important social activity, which helps in shaping the Lue people's political and economic imagination with regards to what it means to be "Tai Lue" in Chiang Kham. Accordingly, this paper will examine the process of Tai Lue local knowledge preservation as a social activity, which is culturally and socially reconstructed within the increasingly globalized context of Chiang Kham.

The paper is divided into three sections, which will demonstrate how Tai Lue local knowledge has been rediscovered and reconstructed in order to strengthen Tai Lue identity in present Chiang Kham. The first section will discuss how Tai Lue local knowledge is selected and essentialized in order to create a distinctly Tai Lue identity among various ethnic groups. This will be followed by an illustration of how local knowledge reconstruction and preservation is a social activity, which accommodates the political and economic desires of various actors and organizations, including the local community, politicians, academic institutions, and local and national governmental organizations. The relationships between these multiple desires and actors constitute a "social assemblage," in which distinct cultural, political, and economic meanings of what it means to "be" Tai Lue in Chiang Kham are continuously negotiated and contested. The last section will situate this process of local knowledge preservation within a "glocal" society, in order to examine how knowledge has been instrumentalized within the process of globalization. Complementary to this glocalization perspective, the concept of "strategic essentialism" will be deployed in order to explain the process of local knowledge preservation as a discursive practice through which the Tai Lue identity is shaped and contested in accordance with individuals' distinct social positions in Chiang Kham. Ultimately, it will be argued that in the case of the Tai Lue in Chiang Kham, local knowledge preservation is an on-going social process whereby distinct cultural, political, and economic meanings are constantly being contested and negotiated by various actors and organizations. Hence, this process will be problematized by situating it within a complex set of relationships within a specific time-space zone, rather than examining it as an isolated and fixed entity.

\section{ESSENTIALIZING TAI LUE LOCAL KNOWLEDGE AS A DISTINCT ETHNIC IDENTITY}

Local knowledge, or indigenous knowledge, is generally discussed as being the binary opposite of Western/scientific/modern knowledge (Nygren, 1999, p.267; 
Akena, 2012, p.601). However, according to Clifford Geertz (2000), local knowledge is essentialized by the individual in order to make sense of the multiple semiotic interpretations that they hold concerning their relationships to the surrounding social and natural world. Geertz emphasized the role of interpretive anthropology due to its conceptual toolkit that facilitates the understanding of local peoples' distinct "cultural" meanings of the surrounding world. Accordingly, interpretive anthropology allows us to "make sense of what they do - practically, morally, expressively ... juridically - by setting it within larger frames of signification, and how they keep those larger frames in place, or try to [organize] what they do in terms of them" (Geertz, 2000, p.180). Thus, analyzing local knowledge from an interpretivist perspective results in the acquirement of highly situated knowledge that is conditional to that specific context. This notion of local knowledge resonates with Yos Santasombat's (2003) research regarding the application of local knowledge within local agricultural production and resource management practices. He argued that local knowledge is a collection of situated experiences that one accumulates from intimate interactions between humans and nature in specific physical, cultural, and historical contexts (p.217).

Since local knowledge is accumulated through continuous interactions among local people within specific localities, it is likely that it is characterized by perpetual power negotiations and inter-relational dynamics. Indeed, according to many scholars (Nygren, 1999; Santasombat, 2003), local knowledge is situated within a complex web of social relations, through which knowledge and power are continually going through processes of incorporation and contestation. This is a result of the assembling of multiple actors, which leads to the creation of a space for the negotiation of local knowledge and practices. This process occurs under dynamic circumstances where various actors contest and appropriate various practical knowledge(s). Therefore, local knowledge should never be examined as a bounded entity, but rather studied as relational and dynamic, and involving multiple social actors and knowledge systems (Nygren, 1999, pp.277-278; Santasombat, 2003, p.43).

With this view of local knowledge in mind, this work will analyze Tai Lue local knowledge that is specifically situated in three Tai Lue villages in Chiang Kham; namely, Baan That Sop Wean, Baan Yuan, and Baan Mang ${ }^{2}$. Ethnographic fieldwork was conducted in these three villages, with a particular focus on local knowledge preservation. Data on Tai Lue local knowledge was collected through participant observation and formal interviews with key informants who are Tai Lue cultural interpreters. Following below are brief descriptions of local knowledge that has been collected and presented in each village museum and historical hall in Baan That Sop Wean, Baan Yuan, and Baan Mang respectively. Lastly, a discussion on how local knowledge has been essentialized as a distinct ethnic identity for Tai Lue in Chiang Kham will be presented.

\section{Local knowledge in Baan That Sop Wean}

I first visited Baan That Sop Wean Temple where I met two Tai Lue cultural interpreters, Ms. Waraporn Wongyai and Mr. Jaras Somrith. At the temple, there is

2The word "Baan" here translates to 'village' or 'community' in a subdistrict under a local municipality administration. 
the "Hall of Tai Lue History," which displays various facts about the Tai Lue people in Baan That Sop Wean. The highlight here is the history of the great Lue migration, which is portrayed in thirteen extravagant paintings. Each of the thirteen paintings depicts a specific historical event of the Lue Chiang Kham; this spans the reasons for their migration from Sipsongpanna to the Lanna kingdom, how they settled down and started their own Lue villages, what their traditional livelihood was like, and the specific traditions of the Lue in Baan That Sop Wean.

\section{Lue in Baan That Sop Wean}

The great migration of the Lue started in the 1800s. To a limited extent, they were forced to move from Sipsongpanna to the principalities of North Siam from time to time. Some Lue people frequently travelled back and forth between the two places, following the caravan trade networks. In 1812, the Lue in Chiang Kham were forced to relocate by the Nan ruler, Chao Sumon Devarat, to the Nan principality. The Lue newcomers were easily able to adjust themselves to the new Lanna community in Nan since they shared similar cultures; in particular, the Tai-Kadai language, as well as their religious traditions and beliefs. Additionally, the Lue people were considered to be hard workers and lovers of peace by the Lanna locals and thus easily integrated into the Lanna community without much violence. After some time, the Lue in Nan moved to Chiang Kham due to the limited amount of land available for paddy cultivation. Most of the Lue who moved to Chiang Kham were originally from Muang Yuan, Sipsongpanna. Hence, the first community they established was named Baan Yuan to commemorate their hometown. Later on they would expand their settlements to other areas such as Baan Mang, Baan That, and Baan That Sop Wean. With regards to the reproduction and maintenance of their culture, the Lue have applied various strategies that merge different aspects of animism and Buddhism. This can be seen in their multiple rituals about rice cultivation, marriage, and merit making for the dead. ${ }^{3}$ Overall, the Hall of Tai Lue History exhibits the historical knowledge of the cultural heritage of being Lue from Sipsongpanna, their ancestors' resettlement, and their traditional ways of life when they were to become the distinct 'Tai Lue of Chiang Kham.'

\section{Local knowledge in Baan Yuan}

While the Hall of Tai Lue History in Baan That Sop Wean preserves and presents the local knowledge of the Lue through the use of elaborate paintings and vinyl charts, the Tai Lue Cultural Center and museum at Yuan Temple exhibits raw materials and real cultural artifacts, such as traditional spinning cotton thread machines, ancient household utensils, collections of silverware and ornaments, and a display of ritual items. One of the most impressive exhibits is the Prasart, or a model of a palace that is believed to be a place where the dead can live in the afterlife. The Tai Lue cultural interpreter who is responsible for the museum is Ms. Hathaithip Choesa-art. She demonstrated how the Lue people greet and welcome guests, and

\footnotetext{
3This brief historical background is summarized from the descriptions of each painting that I had translated from the document, 'The History of Tai Lue in Chiang Kham, Baan That Sop Wean Village, Yuan Subdistrict, Chiang Kham District, Phayao Province' (1977). The English translation is provided in my report of 'LEARNING TO DO ETHNOGRAPHIC RESEARCH: The Lessons of Getting Hands and Feet Wet in Chiang Kham, Phayao'. (Sunanlikanon, 2021) Read further the manuscript on methodological reflection at DOI: 10.13140/RG.2.2.25973.09443
} 
shared the Lue cultural ways of living through the telling of stories that are attached to the various exhibits. For instance, she elaborated on the Tarn Prasart, a ritual for making merit for the dead or making advance merit before death. Tarn is the making of merit by presenting material articles for merit exchange. Traditionally the Tai Lue people have practiced the Tarn Prasart ritual for two reasons: the first was to give necessary goods to the dead, while the second was to build a palace-like house for life after death. Ms. Hathaithip explained that the Lue usually practiced Tarn Prasart for the first purpose, after someone has died or for the yearly remembrance of dead relatives. It is believed that Prasart and other usable gifts will help their dead relatives live comfortably in the afterlife. However, this advance merit making ritual tended to be practiced rarely, with only the most wealthy of the community being able to afford it. As a consequence, Prasart were generally built into very elaborate and exquisite structures. The top of the palace was to be built as high as possible, which demonstrated to the community that there were many people engaging and contributing their labor to wish good fortune for the one who did the advance merit. Furthermore, it was a social event in which the social status of the one who is performing the advance merit ritual could be displayed to the rest of the community. However, Ms. Hathaithip also mentioned that presently, this ritual has come to be considered a merit-making ritual that is mainly for the living rather than the dead. This is because all of the usable goods and bamboo sticks that are used to construct Prasart are then later donated to monks and reused by others in the village.

Apart from the local knowledge that is manifested through these cultural and ritual artifacts, the Tai Lue Cultural Center also displays local weaving knowledge through the exhibition of raw weaving materials and traditional costumes. The first floor of the center is dedicated to exhibiting knowledge about Tai Lue textiles. It displays the whole process of textile weaving: the tools that extract the raw cotton seeds, the making of cotton thread, the natural dyeing process, spinning the threads into cotton yarn, and weaving these yarns into fabrics with distinct techniques for distinguished patterns. This weaving knowledge is essential for Tai Lue women who apply it to make general use fabrics for the household, as well as religious-related fabrics such as Tung-a religious-related flag-, Pa Shed Luang-a Buddhist monk robe-, and $\mathrm{Pa}$ Shed Noi-a general use fabric for monks - . Specifically for religiousrelated fabrics, this knowledge is considered fundamental for all Tai Lue women; that is, it is believed that the women should possess this knowledge since they are deemed to be responsible for making Buddhism prosper through the weaving of these fabrics for monks and other religious ceremonies. Next to the weaving exhibition is a patio where visitors can try weaving first hand. Lastly, the weaving products are also on sale with the prospect of reasonable earnings for the weavers. Notably, it seems that the handmade textiles can be sold at higher costs due to being cultural value-added products.

\section{Local knowledge in Baan Mang}

Methodologically speaking, I applied site observation to look for local knowledge in Baan Mang. Baan Mang is unique in that it is one of the "Tai Lue Communities of Cultural Tourism," which consists of 4 villages namely: Baan That Sop Wean in Moo 1, Baan That in Moo 2, Baan Yuan in Moo 3, and Baan Mang in Moo 4. The main observation site was at the Sean Maung Ma Temple in Baan Mang. 
This temple is promoted as one of the must-see cultural tourist attractions by the Tourism Authority of Thailand (TAT). Another reason was that a weekly cultural market was about to be organized there on the day that I had planned to visit. Therefore, I could observe both the local knowledge that the Tai Lue of Baan Mang have collected and displayed in Sean Muang Ma Temple, as well as the cultural performances portraying Tai Lue identity at the Tai Lue Cultural Market.

Within the temple grounds, there is the Buddhist Hall, a Tai Lue traditional house, the Chalermraja Cultural Center Wat Saen Muang Ma Folk Museum and the Muang Mang Spiritual Hall. In the Buddhist Hall, there is a mural depicting the history of the great migration of the Lue from Muang Mang, Sipsongpanna to Baan Mang, Chiang Kham, as well as the continuation of their traditional way of life in the new settlements. Under the mural, there are descriptions relating to local history, special annual ceremonies and festivals, and their livelihood in the past. These descriptions were provided by the research team of the Tai Lue Cultural Revival project, which will be discussed in the following section. In the middle of the hall, there is the one and only Buddhist statue that is made in the traditional Tai Lue sculptural style. Mr. Suchin Nowichai, the chief director of the cultural and community-based tourism organization of Tai Lue Baan Mang and Baan Yuan, claimed that this statue has a distinct physical shape with a unique, calm, and blessed facial expression when compared to other Buddhist sculptures from the Northern part of Thailand. The sculptor of the statue is of real Lue descent and molded it according to traditional Lue artistic styles. The traditional Tai Lue house located opposite the Buddhist Hall is arranged in the traditional living style of the Lue from Muang Mang. The house is used as an information site for tourists to begin learning about Tai Lue villages and other community-based tourist activities. Located nearby is the Chalermraja Cultural Center Wat Saen Muang Ma Folk Museum. Inside, various cultural artifacts are displaced, such as authentic antique utensils, a model of Mae Sangda's Tai Lue traditional house, and a photograph collection of Rama 9 visiting Chiang Kham. Lastly, there is the Muang Mang Spiritual Hall, which is the only ancient spiritual hall left among the Tai Lue communities in Chiang Kham. Thus, this is the place where Tai Lue people come annually to perform special rituals related to town angels and ancestral spirits.

The folk museum also exhibits a wide range of information, consisting of the history of the migration of the Lue Muang Mang, the establishment of Chiang Kham township, a timeline of historical events in Chiang Kham, and a map of local knowledge centers about traditional cuisines, textiles, Tai Lue local history, and local sacred sites around Baan Mang. There is also a photographic timeline demonstrating how the traditional dresses of Tai Lue women have changed from the past until the present. These exhibitions are a result of the cooperation between the folk museum and Princess Maha Chakri Sirindhorn Anthropology Center. It is worth noting that while the tops of Tai Lue dresses have changed through time, their sinhs - or skirts have remained relatively unaltered. This seems to suggest that Tai Lue sinhs represent some authentic part of Tai Lue female identity. Although there is an abundance of local knowledge provided at Baan Sean Muang Ma Temple, it is noteworthy that it is rather concealed as opposed to being presented animatedly. Moreover, it is questionable if these cultural exhibitions truly engage with the local community and visitors, or whether the local Tai Lue community truly identifies 
with the exhibitions. Hence, it is significant to experience the cultural event to see how the present Tai Lue people in Chiang Kham represent their Lue cultural heritage.

In the Tai Lue Cultural Market at Sean Muang Ma Temple on April 7th, 2021, I observed the vivid cultural performances of the Tai Lue in Chiang Kham. However, it must be noted that on that day, Thai PBS, a public mass media channel, came to record and broadcast the event as well. Therefore, it would be beneficial to view this social event critically using an approach introduced by Erving Goffman, in particular through the lens of frontstage and backstage behaviors. In his works, The Presentation of Self in Everyday Life and Behavior in Public Places, Goffman examined human behaviors through their interactions. He proposed that looking at human behavior is not a given, but rather it should be viewed as a symbolic interaction with other individuals in a particular situation. He referred to a "performance" of interaction as a given behavior and intentional action to shape an audience's understanding of a particular event (Fine \& Manning, 2003, p.45). In this sense, an individual performance cannot be comprehended as such, but it needs to be scrutinized with what Goffman referred to as "frontstage" and "backstage" behavior. According to Goffman, the "frontstage" is a social space whereby a public performance is given by team performers who normatively generalize particular viewpoints for the benefit of the audience. On the other hand, the "backstage" is where the team performers experience contradictory perspectives toward such a public performance. Philip Manning, an adherent scholar of Goffman, supplemented this approach with the "two selves thesis," which provides a comprehensive explanation of public performers. On the one hand, a public performer has oneself to strictly perform what are believed to be public expectations and impressions. On the other hand, the performer manipulates the performance to satisfy or benefit one's own self-interest (Fine \& Manning, 2003, p.46).

Applying Goffman's framework, the Tai Lue Cultural Market will be analyzed using the concepts of frontstage and public performance. Normally, the Tai Lue Cultural Market is held every Wednesday afternoon, rotating among Baan Mang, Baan That Sop Wean, and Baan Yuan respectively. It is organized in order to preserve the culture and create opportunities for Chiang Kham residents, children, and visitors to experience the cultural events. On the $7^{\text {th }}$ April, 2021, there were three zones accommodating various cultural events. The main stage was used for onstage performances and was located in front of the Buddhist Hall of Sean Muang Ma Temple. There were many cultural performances at the main stage, such as contemporary folk music, Tai Lue folksongs, Tai Lue dances, and Tai Lue costume explanations. Another area was a patio near the Tai Lue Traditional House, which was arranged for traditional dancing and drum performances. The last zone was organized with lines of small booths arranged along the pathway from the entrance of the market to the front of the Traditional House. This was considered a selling area where local villagers could sell their products: traditional foods, woven bags, handmade goods, and so on. The booth at the front of the House arranged traditional Tai Lue toys where children could play and learn about Tai Lue culture. However, some skepticism emerged when the media recorded children playing with a Mark Luk Yon, a fabric ball, in a similar manner to basketball, without any explanation to its original and intended use. Traditionally, a Tai Lue girl makes a 
Mark Luk Yon to later throw it to a potential life partner during special events and festivals. It is likely that playing with the Mark Luk Yon has been modified to attract children to experience Lue culture as something fun rather than a boring traditional event. From my critical observation, all public performances at the Tai Lue Cultural Market seemed to be well-planned representations of both authentic and contemporary Tai Lue culture. These vivid cultural representations show the pride of Tai Lue people in Chiang Kham, who rigorously promote and encourage local people and visitors to enjoy and experience the richness of Tai Lue culture. Ultimately, they seemed to make use of local knowledge by converting it into economic capital as I could observe the economic distribution from local vendors participating in the Cultural Market. The vendors converted their local knowledge about weaving, cooking, performing folksongs, and playing traditional musical instruments into public performances that allowed the audience to vividly experience the Tai Lue culture of Chiang Kham. With all component props of the front, which are constituted within a particular time and space, the Tai Lue peopleas both performers and audience-were oriented to normative definitions of that frontstage, and performed their social roles while exercising their personal desires (Goffman, 2008, pp. 21-22) of local knowledge preservation through commodification in a community-based tourism setting.

\section{Presupposition of local knowledge essentialization}

From the collection of this local knowledge(s) from different villages, it may be true to state that Tai Lue local knowledge is being essentialized by the Tai Lue in Chiang Kham, especially the knowledge from Baan That Sop Wean, Baan That, Baan Yuan, and Baan Mang. All of this has played an important role in the cultural revival project. The essentialization of local knowledge can be considered as a continual process aiming to recover indigenous knowledge, which is deeply rooted in Lue cultural heritage and still being practiced today. I use the term "essentialization" 4 to connote a particular process that revives certain essential cultural elements from Lue ancestors. Now residing in Chiang Kham, Phayao, Thailand, it has become very much effortless for the Tai Lue to internalize various aspects of Thainess and integrate themselves into Thai mainstream society. However, the essentialization of Tai Lue local knowledge has helped Lue descendants from Sipsonpanna to preserve their ethnic identity by reinforcing many of their cultural roots. In addition to reviving local knowledge, essentialization also aims at preserving and institutionalizing it as a representation of a particular ethnic identity that is distinct from being Thai.

The main reason why Tai Lue locals in Chiang Kham need to essentialize their culture is strongly related to how it becomes a means for negotiating their status. Concerning cultural essentialization, it is important to take into account its relational context within the processes of globalization, where local culture and economy inevitably and reciprocally interact with the global culture and economy. I will further elaborate on the concept of globalization and glocalization in the last section; however, at this point, I will attempt to demonstrate that glocalization is always set

4The notion of 'essentialization' is developed from the essentialist approaches of anthropological studies which examine ethnicity from the collective intersubjectivities among people in the same ethnic group who share cultural understandings, whether consciously or unconsciously, of their ethnic identity (Narayan, 2005, p.273). 
as a contextual background for local knowledge essentialization. This phenomenon should be analyzed alongside the various relationships between distinct actors and social institutions at local, regional, and national levels since they are influenced by global economic factors. On the one hand, the global economy partially, if not directly, affects the way national governments implement policies that are meant to stimulate the national and local economy. On the other hand, local people have adapted themselves to keep up with the rapid global changes in the economy.

People in Chiang Kham have also developed their way of living in urbanized towns, adopting bureaucratic occupations rather than the ones linked to agriculture. Furthermore, Chiang Kham has accommodated a vibrant and diverse set of cultures throughout its history. Due to this, Chiang Kham has become rich in cultural capital, becoming a destination for both domestic and international tourists from the 2010s onward. Being home to different ethnic cultures has pushed the ethnic people in Chiang Kham to negotiate their political and economic status through revitalizing and essentializing their cultural particularities. In this case, the Tai Lue have constructed and legitimized a particular political identity that has allowed them to negotiate within particular economic fields and ultimately integrate their livelihoods into the mainstream tourism economy. To strengthen this distinct identity involves not only individual actors, but it also involves other informal and formal organizations constituting an assemblage of cooperators with shared political desires.

From my observations, local knowledge preservation is by no means practiced solely to discover and clutch tightly to some type of authentic "Lueness" from Sipsongpanna. Rather, the essentialization of local knowledge is to uncover all of the possibilities that have the potential to help the Tai Lue in Chiang Kham negotiate their political and economic status as an ethnic Tai Lue in mainstream Thai society. Under this presumption, local knowledge preservation should therefore be critically examined as a social assemblage in which many contributors are rigorously involved in the Tai Lue cultural revival project that has been actively implemented from 2015 onward. Hence, in the next section, I will discuss how Tai Lue local knowledge preservation emerged out of a complex assemblage of the political desires of multiple relevant agencies.

\section{THE ASSEMBLING OF POLITICAL DESIRES IN TAI LUE CULTURAL REVIVAL PROJECTS}

There are many actors and organizations involved in Tai Lue cultural revival projects. Furthermore, there is a rich and continuous history of attempts by communities to recover Tai Lue culture. The first contemporary attempt was from the local politician, Ms. Laddawan Wongsriwong, who was once a government spokeswoman for the former Prime Minister Anand Panyarachun between 1991 to 1992. ${ }^{5}$ She can be considered as a successful Phayao woman of Lue ethnic background who is well-known for her strong determination to solve social

\footnotetext{
${ }^{5}$ During the two times that Anand was in premiership, he successfully initiated economic and political reforms after the political unrest from the pro-democratic demonstrations and military coups. With his selected cabinet of men and one woman, Laddawan Wonsriwong, he launched many reform projects and successfully paved the way to a modern democratized Thailand (Hewison, 2021, p.180).
} 
problems in Phayao and Chiang Kham, specifically prostitution and the HIV/AIDS outbreak. ${ }^{6}$ During her time in office, she helped allocate more funds of the national budget for development projects in Phayao province. In the case of Chiang Kham, she helped request a budget from the Tourism Authority of Thailand (TAT) of around 3 million baht in order to transform a particular building into the Wat Yuan Cultural Center and Tai Lue Textile Museum in 1993 (Museum Thailand, 2019). She also channeled around 250,000 baht of the state budget to six small Tai Lue textile weaving manufacturers in Chiang Kham in order to create jobs in the area and combat illegal human trafficking issues. From the 1990s-2000s, she worked tirelessly to improve the quality of life for the Tai Lue in Chiang Kham, as well as the people of Phayao more generally (Nishizaki, 2011, p.1575).

Furthermore, according to Mr. Suchin, the chief director of the cultural and community-based tourism organization and the director of the Tai Lue Association, the serious cultural revival projects began to be launched from 2015 onwards. These projects were developed through the cooperation of the local people, municipality, academic institutions, and national organizations- specifically the TAT, which is responsible for allocating the budget to boost local community-based tourism. It can be deduced that through the previous work of Laddawan, opportunities were created that facilitated the assembling of various individuals and organizations who shared similar views on development. However, as Nishizaki (2011) asserted, the rise of Laddawan should be situated within the complex local-national context. At that time, the HIV/ AIDS epidemic was in full effect in Phayao, while Thailand was going through the rapid development of its industrial economy, which affected the social norms on materialism (p.1593). Additionally, there was a massive internal migration from the countryside to Bangkok as people sought out jobs. Unfortunately, many women who migrated to the cities at this time fell into prostitution. Thus, the government at the time increased the budget allocated to rural areas in order to pursue development projects and facilitate job creation in the rural provinces. The distribution of the national budget for local development can be considered an effect of glocalization where, at the time, the world was evolving around developmental schemes driven by a humanitarian ethics. Thus, an increase in the development budget was allocated to Chiang Kham, not only because of the personal connection of Laddawan, but also due to pressure coming from the international development community.

It is possible that the Tai Lue cultural revival projects have emerged out of a social assemblage that is made up of local individuals' and local-national organizations' endeavors to satisfy the diverse interests of the local culture within a specific spatio-temporal context. Therefore, the cultural revival project and local knowledge preservation shall be problematized in relation to a particular context. In Chiang Kham, for instance, cultural revival projects were initiated from the tourism policy of the TAT, which included tourism campaigns called "12 Cities Hidden

${ }^{6}$ Laddawan was promoted to be an anchorwoman for the state-owned media channels 9 and 11, which made her well known nationwide. This career gave her opportunities to work seriously on prostitution issues and become recognized by many prominent politicians. Later in 1991, she was the only woman appointed to be a government spokeswoman in Anand's government. Furthermore, she later joined political parties to work out various social issues such as citizenship, prostitution, and development projects for the community (Nishizaki, 2011). 
Gems" and "12 Cities Hidden Gems Plus" from 2015 to 2018 (Aryuwatthanachai, 2019). This government policy generated many cultural revival projects throughout the country in order to find potential towns and communities for tourism promotion. Thus, the revival of local history and local knowledge in Chiang Kham has probably proceeded from the 1990s until today, in accordance with contingent local-national politics and social situations. It has developed from the original aims of creating jobs, combating prostitution, and promoting local knowledge on textiles and weaving, to enhancing local knowledge preservation and local management capacities to accommodate an increasing amount of tourists who wish to experience the Tai Lue culture and way of life. Within this context of rapid social, economic and cultural change, the cultural revival projects have become a political space within a social assemblage that is composed of various individuals and organizations at the local, provincial, and national levels.

Social assemblage, as a generic term, generally refers to a social gathering of various groups of people; however, it also has the theoretical meaning of an emerging community of potential. According to Tanabe (2016), social assemblage is a concept that can be used to analyze a community that is within a dynamism of becoming, and which is comprised of diverse social components with distinguishing characteristics and capacities - even if this community also shares value-driven desires. When the heterogeneous desires of the social components find their place within this contingent environment, they will collaborate with one another. This results in the emergence of the social assemblage, which transforms into a community of potential where possibilities can be extended and sustained. This conception of social assemblage will be deployed in order to elaborate on how Tai Lue cultural revival projects accommodate the political desires of various actors and organizations at all of the levels mentioned above.

Considering the local individuals and organizations, they seemingly participate in cultural revival projects with distinct desires and purposes. A famous elderly woman of Baan That Sop Wean, grandma Sangda, is a Tai Lue local sage on weaving. She continues to weave in the traditional Tai Lue style, making red-colored handbags and demonstrating weaving techniques under her traditional house. She continuously involves herself in all of the cultural revival projects. She shared that she had an expedition to Sipsongpanna with the local municipality officers to learn about the Lue livelihood over there. For grandma Sangda, the expedition to Sipsongpanna was a pleasant trip to a foreign country, but it did not change her perception of what was "authentically" Lue; she could not find many differences between the Lue of Sipsongpanna and the Lue of Chiang Kham. For her, participating in Tai Lue cultural revival projects seems to help her carry on the preservation and transferal of local knowledge about traditional Lue textiles. She is fortunate in that she can make a living by advertising her home and lifestyle as the traditional Tai Lue way of life. Her house is preserved in the authentic Tai Lue traditional architectural style, and it has also been reproduced at a small level to display it at the Chalermraja Cultural Center Wat Saen Muang Ma Folk Museum. Moreover, through the cultural community-based tourism, grandma Sangda's house is mapped as a must-visit site in the cultural tour brochures. It is presented as a living museum where tourists can visit, listen to the oral history of grandma Sangda's life, enjoy sightseeing around her house, and shop for souvenirs. In sum, 
joining the cultural revival projects and taking part in cultural community-based tourism has allowed grandma Sangda to both make a living and preserve the Tai Lue ways of life simultaneously. For grandma Sangda, her lifestyle has been essentialized as an authentic Tai Lue way of living. In addition, her knowledge of weaving, the oral history of her life, and her traditional house are also essentialized through the proclamation that they are the closest to the authentic Tai Lue way of life. This essentialization is, whether consciously or not, commoditized to attract visitors to spend time and money at her place. With the ability to commodify life stories and products, many other crafters and weaving vendors have asked her if they could sell their products at her home.

Cultural revival projects for the local government and institutions, such as the Tai Lue Association, seem to represent something more than cultural and local knowledge preservation. As both of these can benefit from the increased allocated budget from TAT policies and other national-level governmental organizations, their participation in the cultural revival projects is likely obligatory and goal-oriented. From an optimistic perspective, it is most likely that these institutions can play crucial roles in facilitating the implementation and success of these cultural revival projects as they have the most knowledge concerning the standardized measurements of such proclaimed policies. On the other hand, these plans are set up by hierarchical bureaucratic offices and are strictly implemented; it is therefore less likely that these cultural revival projects incorporate the genuine participation of the local community. However, the structure of the Thai bureaucratic system directly affects the way governmental organizations spend their budgets, which has led to multiple financial and operational difficulties. Thus, the best way to spend the budget in helping subsidize local cultural centers, learning centers, museums, and local sages, is to use the budget for infrastructure construction projects such as cultural center restoration, temple renovation, streetlight decoration, and so on. Furthermore, as government units receive their budget, they tend to organize initiatives along with other actors, such as the private sector, academic institutions and community organizations, in order to enhance local people and communities' capacities; in fact, due to their action plans' strict rules and expected outcomes, government offices cannot do much work unless they collaborate with these other institutions.

Political bodies like municipalities or provincial offices must strictly follow rules and regulations which sometimes hinder them from achieving promising outcomes. Therefore, the responsibility to manage cultural revival projects for promoting cultural community-based tourism needs to be handed over to civil society or other social institutions. Buddhist and academic institutions are part of civil society and can assist in effectively preserving and promoting Tai Lue local culture, as in the case of Chiang Kham. Buddhist temples in particular have prominent positions that can support local knowledge preservation in Chiang Kham. In all four of the cultural community-based villages, temples act as cultural centers and folk museums where local knowledge, in the form of local history, cultural artifacts, folklore and so forth, is stored neatly inside the monastic area. This is due to the fact that the Tai Lue have traditionally used temples and monastic areas not only for religious purposes, but also for other social gatherings and educative activities. It is not only within temples that we find cultural centers with informal 
education for those interested, but such education can also be found in various buildings of the local public school, the local Non-Formal Education offices, and other local associations. Therefore, it is appropriate to assume that Buddhist institutions have prominent roles that can support local culture and knowledge preservation; they are considered to be the heart of the Tai Lue community and serve to maintain their strong religious ethnic identity. Regarding the religious ethnic identity of the Tai Lue, we can see that even if they are ethnically distinct from their Lanna or Thai counterparts, religiously they share similar Buddhist ideas and this engenders compatibility for living in Thailand. Therefore, the essentialization of Buddhist identity is pursued in order to gain acceptance among Thai people, authorities, and Thai Buddhist ideology. With the Tai Lue's high regard for Buddhism, it is not surprising that their temples are so beautifully maintained and in such good shape. Moreover, it seems that these temples receive increased budgets in order to support infrastructure that can be used to organize social activities. Taking all of this into account, religious institutions cannot escape from the complex political desires of the local people, local government, and other actors of civil society that take part in the cultural revival projects - even if there are different motivations.

Another civil society actor that is highly significant in making cultural revival projects possible is academic institutions, such as Silpakorn University and the University of Phayao. According to Mr. Suchin, the cultural revival project began with local knowledge recovery. To achieve this, the Tai Lue Association sought out professional researchers, which in this case were found in Silpakorn University. In 2015, academicians from the university began various research projects on local knowledge recovery in their attempt to revitalize the history of the Tai Lue of Chiang Kham. Most of their data came from the social memories of the village elders, as well as from taking various trips to Sipsongpanna. How the Tai Lue was redefined came from mutual understandings of the various groups involved, which was facilitated by conducting participatory action research among the elderly, local sages, Tai Lue associates, Buddhist monks, academics and local officials. For local government officials, academics in particular were a key group that could offer suggestions to them regarding the accomplishment of the development plan. More importantly, development policies emphasized the empowerment of local people's capacities to achieve various sustainable development goals by subscribing to a philosophy of living self-sufficiently. Therefore, local and provincial universities stepped in to meet both the local government's expectations and the university's roles and social responsibilities. Thus, Chiang Kham became a research site for academics to pursue research and further their academic careers. For example, multiple research projects have been conducted in the area focusing on the development guidelines for tourism management, the development of cultural capital of Tai Lue communities, the development of local government organizations and civil society mechanisms to increase the potentiality of the community economy, and most relevant of all the Tai Lue community development project in Chiang Kham with its cultural innovations for quality of life and cultural tourism support (Wiangkham, 2015; Butri, 2020; Faculty of Architecture and Fine Arts, 2021). These academic research projects are also a consequence of glocalization in that the local reacts to international and national policies for economic development. Doing 
research is a first step to gain comprehensive cultural knowledge for initiating local development plans. Some academic faculties have even received research awards for promoting public well-being and empowering communities with social innovations which strengthen their affiliations' reputations. Due to its high degree of success, the Minister and officials from the Ministry of Higher Education, Sciences, Research and Innovation visited the University of Phayao and the Tai Lue Cultural Market in Chiang Kham to support the social and economic innovations of cultural community-based tourism. The Minister maintained that it is crucial that sustainable and stable cultural tourism be promoted, as well as the integration of operations between local governments and related network partners in order to create and manage a cultural space that is geared towards sustainability. By doing so, the local knowledge, cultural roots, ethnic identities, and livelihoods are harmoniously preserved through the new representation of a cultural market where local knowledge can create added economic value and help facilitate a self-reliant economy within local communities (Program Management Unit on Area-Based Projects, 2020). The statement of the Minister precisely shows that local knowledge and culture will be well-preserved only through its commodification within the local tourism industry. Additionally, this reinforces the national policies on economic development, which emphasize the strengthening of local communities' capacities to promote a self-sufficiency economy for the people.

Taking all of these actors' and organizations' aspirations into account, local knowledge preservation conducted through cultural revival projects of the local and national organizations demonstrates a complex assemblage of political desires, which interact with one another and create the perfect conditions to make local knowledge survival possible. As I mentioned previously, local knowledge preservation is not simple. Rather, it is a complex set of social activities that emerge out of a relational dynamism involving multiple interrelated actors and agencies. Moreover, distinct political aspirations are continuously being negotiated within a space of constant contestation over the meaning of what it means to be Tai Lue. The outcome of Tai Lue local knowledge preservation is a cultural tourist commodity. Although the actors came into collaboration with different political desires, they have sorted out similar win-win goals and practices, which have allowed them to all obtain various benefits. Furthermore, the contingency of the social assemblage has a particular relationship with the broader conditions of the economy. Glocalization is always the contextual background of the social assemblage, as well as the actors and organizations that compose it. Therefore, in the last section, I will take a glocalization approach to discuss how local knowledge preservation relates to the economy in the context of a globalized Chiang Kham.

\section{INSTRUMENTALIZING LOCAL KNOWLEDGE AS AN ECONOMIC AND POLITICAL TOOL TO NEGOTIATE IN A GLOCAL SOCIETY}

In the last section, I attempt to elaborate on how local knowledge preservation is a complicated social activity in which local and national actors and organizations contest various meanings of what local knowledge is and how it can be utilized. It is inevitable to put local knowledge preservation within the broader context of a 
local-global interactional process. Henceforth, I will engage with the theoretical discussion of glocalization, which is developed from the conceptual viewpoint of a local-global interdependence. Then, I will examine local knowledge with an analytical perspective of strategic essentialism, which helps to clarify the processual transformation of local knowledge from a general view as a priori essence. In other words, I propose to look at local knowledge as a set of interactions among multiple actors who are situated within a context of continual local-global relations. In this way, we shall conceive Tai Lue local knowledge within a set of power relations in order to understand its viability rather than preserve its immutability.

Taking the local knowledge of the Tai Lue in Chiang Kham as the center of analysis, we find that it is not mere absolute, unchanging knowledge. Rather, it is knowledge that is undergoing continuous change and is situated within experiential learning environments. As mentioned previously, Tai Lue local knowledge is situated within a relational dynamism of local-global relationships, where global influences can penetrate into local Tai Lue communities. In this sense, Tai Lue communities and people have fallen, whether consciously or unconsciously, into the waves of globalization. However, globalization here does not connote the process in which a dominant global culture is homogenizing various heterogeneous societies. In other words, globalization should not be conceived as a process that overrides various cultural beliefs such as nationalities and ethnic identities. Rather, globalization relates to the interrelations of the local and global, or in other words, glocalization. Robertson (1995) criticized the homogenization perspective because it fails to respond to two important issues. First, it fails to analyze the "local" as a gradually and constantly constituted process that is on a trans-local basis. Second, it neglects the particularity of the "local," therefore ignoring the various constituents, conditions, and positions of a particular community in relation to time and space and in interaction with global influences. Thus, it is necessary to introduce the concept of glocalization in order to better understand these local-global relations (p.26).

Glocalization has been conceptualized by many scholars in order to supplement the ambiguous "globalization" framework. Roudometof (2015) attempted to comparatively analyze the conceptions of glocalization by focusing on two influential scholars, Robertson and Ritzer, and suggested interpreting the concept as analytically autonomous. According to Roudometof, Robertson conceptualized the notion of "glocal" as being made up of a local-global monistic substance. That is to say, globalization for Robertson is realized concretely only at the local level. Globalization cannot be understood as something that exists in itself, but only in relation to effects on the local ground. Conversely, the notion of the local can never be purely identified without considering global processes. The local is always constituted in response to or under the influence of the global. However, Ritzer's notion of glocalization is understood as the opposite of "grobalization." Ritzer used binary opposition in the interpretation of glocalization as denoting the explicit acknowledgement of cultural heterogeneity of the locale, which is constantly struggling within various power relations that expand to the global level. Grobalization, on the other hand, is defined as a process that aims to override the local and extract profits by homogenizing local cultures. The West has tended to facilitate the process of grobalization under different guises and in different eras, for 
example, those of neo-colonialism, modernization, McDonaldization, Disneyization, and so on. For Ritzer, local-global relations are totally independent. Local products or services that have already been in contact with global flows cannot claim local authenticity. Drawing from these two scholars, Roudometof argued that these two interpretations of glocalization complement each other, yet they neglect the autonomy of localities in entertaining globalities. He suggested understanding glocalization as a process in which localities conceive globalization as a wave-like process spreading throughout the world. Within this spatio-temporal context, the local can absorb, learn, and reflect on the global phenomenon, before responding to various issues on the global stage. By considering globalization as a wave, analysis is able to take into account various distortions and refractions that occur as the "wave" comes into contact with multiple influences of the local actors. As a result, "glocalization is globalization refracted through the local," which then autonomously reshapes itself at the end stage (Roudometof, 2015, p.400). Following this interpretation, local-global relations are situated within a set of power relations where locals have the agency to operate in a reciprocal or resistant manner to various global influences.

In light of glocalization, Tai Lue local knowledge preservation is clearly situated within such an environment where the flow of globalizing processes come into contact with the local-nation (Thailand), local-province (Phayao), and local municipality of Chiang Kham. At the same time that local tourism has generated more money for the local community, it has also brought forward the opportunity for local Tai Lue to learn and define in their own way what local tourism means. Basically, in the case of Chiang Kham, the Tai Lue people have essentialized their local knowledge about historical events in order to commodify it and integrate into the global economic community. Thereafter, a social assemblage begins to emerge out of multiple contingencies, and initiates various local knowledge revival and preservation projects. Cultural community-based tourism is notably the result of global culture driven policy, national policy implementation, and at the same time, the local reaction to such global and national influences. This is how the global culture of development influences local knowledge preservation and the local development of a self-sufficient economy. The assembly gathers from the localglobal interactional relationships negotiating in the process of glocalizing local knowledge. It is not so much that glocalizing local knowledge is unauthentic, but it is rather strategically essentialist. This statement resonates with my presupposition in the first section that Tai Lue local knowledge has been constructed under a process of essentialization, and as a strategy for the Tai Lue to politicize their ethnic identity.

Strategic essentialism is a concept introduced by Gayatri Chakravorty Spivak, who studies the subaltern people and colonial issues. It has been used to describe the discursive practices of heterogeneous marginalized groups of people who collectively engage in an essentializing and institutionalizing process to construct a common identity and obtain negotiable power. This essentialization of identity henceforth is considered as a strategy to contest various forms of domination, modes of exploitation, or asymmetrical classification (Eide, 2010, p.76; Jessop \& Sum, 2012, p.89). From this viewpoint, strategic essentialism is applicable to explain the process in which the Tai Lue of Chiang Kham have become involved in local knowledge 
revival and preservation. Tai Lue local knowledge is positively instrumentalized, or even institutionalized, as an essential and distinct ethnic identity of the Tai Lue of Chiang Kham in order to either struggle against or integrate into Thai mainstream culture and the global economy. Through strategic essentialization, they attract both domestic and international tourists to visit and experience the Tai Lue traditional way of life. In this way, Tai Lue communities can benefit financially since they have strategically essentialized their local knowledge to strengthen their Tai Lue ethnic identity. To concretely operationalize my approach, local knowledge, such as local history, weaving and local textile patterns, and cultural performances, is commoditized in order to integrate the community with the regional, national, and global economy. It is here where particular traditional cultures are considered exotic commodities that can be sold to tourists who wish to experience the Tai Lue way of life.

Apart from negotiating in the economic field, the Tai Lue of Chiang Kham have also constructed a strong political identity that has been used to acquire economic and political privileges through various mechanisms that are constituent of the assemblage of local actors and organizations. The assemblage of Tai Lue entrepreneurs, cultural interpreters, local sages, local governments, and academics constitute the strength of Tai Lue ethnic identity, which is a result of the process of local knowledge essentialization, commoditization and commercialization. Owning Tai Lue cultural identity and knowledge can pave the way to participate in a power arena of economic and political negotiation. For instance, stateless Tai Lue from Laos, who acknowledge their illegal status, can negotiate their political status instead by performing their cultural capacities - through for instance weaving Tai Lue style textiles - and integrate into the Thai economic sphere by emphasizing their ethnic identity rather than their national identity. Consequently, Tai Lue communities become a potential glocal society where ethnic identity helps strengthen their political and economic status regardless of their legal status of being Thai citizens or stateless Tai Lue. Additionally, those Tai Lue who settled long before the new migrants, have also been able to negotiate what it means to be "Tai Lue" by comparing themselves to other nearby Tai Lue communities and other ethnic neighbors. This shows that there are several kinds of Tai Lue knowledge essentialization that are in competition with each other. The Tai Lue of Baan That Sop Wean, Baan Yuan and Baan Mang have decided to assemble and institutionalize the idea that "authentic Tai Lueness" is dependent on being the original descendants of Sipsongpanna. On the other hand, the Tai Lue of Baan Lha claim their origin from Muang Lha, a larger town in Sipsongpanna. In these circumstances, many Tai Lue communities compete to have their representation of Tai Lue culture recognized by the Chiang Kham district. At the same time, other Lue and ethnic group representations are marginalized, such as the Pa-O and Tai Yai. Ultimately, Tai Lue culture from Baan That Sop Wean, Baan Yuan and Baan Mang has become institutionalized and now represents the official image of all the communities in Chiang Kham, even though there are various ethnic groups residing in the area. 


\section{CONCLUSION}

Tai Lue culture in Chiang Kham seems to be a modified local culture, which has been through various processes and consists of the multiple demands of several actors that include the local community, elder sages, local politicians, the local government, academic institutions, and national government sectors. This diverse set of actors and processes, and the relationships they have with one another, make up a particular social assemblage. From this assemblage emerges local knowledge preservation projects, which I have attempted to demonstrate are continually undergoing a process of negotiation and contestation. Taking Tai Lue local knowledge preservation in Chiang Kham as empirical evidence, I argue that it is problematic to analyze local knowledge preservation as an explicitly permanent and unchanging phenomenon. Rather, it is a complex and continual social process, which involves many agencies within various power relations that are negotiating and redefining local knowledge to enhance their own benefits. As a result, local knowledge is essentialized in accordance with each actor's aspirations. For some actors, such as Laddawan and grandma Sangda, local Tai Lue knowledge is the essence of "being Tai Lue" in Chiang Kham because they affiliate local knowledge with ethnic pride, and have been able to accumulate a great amount of cultural capital that is meant to be preserved and transferred to future generations. Local knowledge as such is also instrumentalized as a tool for economic gain. For instance, the unique pattern of Tai Lue textiles, the local histories of the great migration, folk songs and Tai Lue cultural performances have all been instrumentalized into cultural commodities that have helped create jobs, generate monetary circulation within the community's economy, and promote sustainable self-sufficiency. Through these social mechanisms, Tai Lue local knowledge advances its political extent by institutionalization. Tai Lue local knowledge preservation is thus a perpetual process that aspires to strengthen Tai Lue ethnic identity by representing it as a distinctive local identity of the people of Chiang Kham as they confront various forms of nationalism and globalization. All in all, the perspectives of essentialization, instrumentalization, and institutionalization are discursive practices of strategic essentialism that Tai Lue communities and relevant actors use when encountering globalizing influences in Chiang Kham. To conclude, local knowledge preservation should not be superficially studied; rather, it should be examined within specific spatio-temporal contexts, and as a complex social assemblage made up of various Tai Lue actors alongside other agencies in a globalizing Chiang Kham.

\section{ACKNOWLEDGEMENTS}

I would like to thank the following for being a part of this work. Firstly, as a doctoral student, I would like to thank the Doctor of Philosophy Program in Social Science (International Program) in the Faculty of Social Sciences, Chiang Mai University, under the CMU Presidential Scholarship. Without this scholarship, I would never have had the opportunity to explore the social world with social science academic lens. Secondly, I am grateful for helpful suggestions from Prof. Yos Santasombat and Miss Sujiwan Yimyuan that made the trip to Chiang Kham practically happen. Thirdly, I am thankful that my classmates, namely Rain, Zai, and 
Oonkeaw, were willing to jump into the unknown together. They have put their efforts to realize the Chiang Kham trip and gone through every process. I would say I am lucky having you in this long and tiring PhD journey and hopefully we can finish this together. And lastly, I would like to thank Alex for spending time reading, talking, and reflecting your thoughts on this work. I do value your critical comments, and I always keep in mind and also subscribe to the praxis ways of being an academic person.

\section{REFERENCES}

Akena, F. (2012). Critical Analysis of the Production of Western Knowledge and Its Implications for Indigenous Knowledge and Decolonization. Journal of Black Studies, 43(6), 599-619.

Anukunwathaka, N. (2013). Chīang Kham: Mữang Hǣng Thailừ Phaìtai KrasæThōngthin Niyom [Chiang Kham: Tai Lue Town Under the Movement of Localism]. In P. Chai-maungchuen \& P. Seansa (Eds.), Mut Maì Prawattisat Lānna- [Lanna History Marker] (pp. 316-331). chapter, East Publisher: Bangkok. (in Thai)

Aryuwatthanachai, K. (2019, January 19). Thuaring Phayao Chom Withī Thai Lư Chak Chiang Kham Thưng Phū Sāng [Touring in Phayao: Experience Tai Lue Ways of Life from Chiang Kham to Phu Sang]. https://www.posttoday.com/life/ travel/577508.

Butri, P. (2020, August 26). Miti Mai "Kał Thai Lü" "Pan Su' 'īweñ Chumchon Songsœèm Thōngthieo - Setthakit [New Dimension "Kad Tai Lue" Molded into Community Events for Promotion of Tourism - Economy]. MGR Online. https:/ / mgronline.com/travel/detail/9630000087751. (in Thai)

Eide, E. (2010). Strategic essentialism and ethnification: Hand in glove?. Nordicom Review, 31(2), 63-78.

Faculty of Architecture and Fine Arts. (2021, January 28). Khana Sathāpattayakammasaz Læ Sinlapakam Sał Dai Rap Rāngwan "Rīan Thōng " Nai Ngān Phayao Wichai Khrang Thi Sip [Faculty of Architecture and Fine Arts Received the "Gold Medal" Award at the 10th Phayao Research Fair]. University of Phayao. https:/ / up.ac.th/th/NewsRead.aspx?itemID=23270. (in Thai)

Fine, G. A., \& Manning, P. (2003). Erving Goffman. In Ritzer, G. (Ed.), The Blackwell Companion to Major Contemporary Social Theorists, 34-62. Blackwell Publishing.

Geertz, C. (2000). Local Knowledge: Further Essays in Interpretive Anthropology. Basic books.

Goffman, E. (2008). Behavior in Public Places. Simon and Schuster.

Hewison, K. (2021) Anand Panyarachun and the Making of Modern Thailand: Dominic Faulder (Singapore: Editions Didier Millet, 2018), Journal of Contemporary Asia, 51(1), 179-186, DOI: 10.1080/00472336.2019.1663632

Jessop, B., \& Sum, N. L. (2012). Cultural political economy, strategic essentialism, and neo-liberalism. In Künkel, J. \& Mayer, M. (Eds.), Neoliberal Urbanism and its Contestations: Crossing Theoretical Boundaries, 80-96. Palgrave Macmillan. 
Museum Thailand. (2019, July 2). Centre of Tai Lue Culture (Wat Yuan). https://www.museumthailand.com/en/museum/Centre-of-Tai-Lue-CultureWat-Yuan.

Narayan, B. (2005). Anthropological Approaches to the Study of Ethnicity. The Oriental Anthropologist, 5(2), 269-280.

Nishizaki, Y. (2011). Prostitution and female leadership in rural Thailand: The story of Phayao Province. Modern Asian Studies, 45(6), 1535-1597.

Nygren, A. (1999). Local knowledge in the environment-development discourse: From dichotomies to situated knowledges. Critique of Anthropology, 19(3), 267288.

Prawattisał Chāo Thai Lữ Chīang Kham Bān Thatsop Wǣn, Tumbon Yuan, Amphoe Chiang Kham, Jungwad Phayao [The History of Tai Lue in Chiang Kham, Baan That Sop Wean Village, Yuan Subdistrict, Chiang Kham District, Phayao Province]. 1977. 'ekkasān 'atsamnao [a copied document] (In Thai)

Program Management Unit on Area-Based Projects. (2020, November 3). Prof. Dr. Anek, Minister of MHESI, Nunkaz Watthanatham Thai Lü Sāng Phünthi Thañg Setthakit Khōng Chumchon [Prof. Dr. Anek, Minister of Higher Education, Sciences, Research and Innovation, supports Thai Lue culture: Create a community economic space]. Ministry of Higher Education, Sciences, Research and Innovation. https:/ / www.mhesi.go.th/index.php/pr-executive-news/2020-tai-lue.html. (In Thai)

Robertson, R. (1995). Glocalization: time-space and heterogeneity-homogeneity. In Featherstone, M., Lash, S., \& Robertson, R. (Eds.), Global Modernities, 25-44. Sage.

Roudometof, V. (2015). Theorizing glocalization. European Journal of Social Theory, 19(3), 391-408. https:/ / doi.org/10.1177/1368431015605443

Santasombat, Y. (2003). Biodiversity, Local Knowledge and Sustainable Development. Regional Center for Social Science and Sustainable Development, Faculty of Social Sciences, Chiang Mai University.

Sunanlikanon, N. (2021, July 23). Learning to do Ethnographic Research: The lessons of getting hands and feet wet in Chiang Kham, Phayao. ResearchGate. https://www.researchgate.net/publication/353403978_LEARNING_TO_DO_ ETHNOGRAPHIC_RESEARCH_The_Lessons_of_Getting_Hands_and_Feet_W et_in_Chiang_Kham_Phayao. DOI: 10.13140/RG.2.2.25973.09443

Tanabe, S. (Ed.). (2016). Communities of Potential: Social Assemblages in Thailand and Beyond. Silkworm Books.

Wiangkham, T. (2015). The Development Guidelines for Tourism Management Plans: A Case Study of Chiang Kham, Phayao (Master Dissertation). Silpakorn University, Bangkok. 